УДК

UDC

DOI: $10.17223 / 18572685 / 65 / 4$

\title{
Bishop Jozef Gaganec (1793-1875) - a leading figure of the religious, national and cultural life of Greek Catholics and Rusins in the mid-19th century in present-day Slovakia*
}

\author{
J. Coranič \\ Prešov University in Prešov \\ 2 Bishop Gojdič Street, Prešov, 080 01, Slovakia \\ E-mail: jaroslav.coranic@unipo.sk
}

\section{Abstract}

The second bishop of Prešov, Jozef Gaganec is one of the greatest figures in the history of the Greek Catholic Eparchy of Prešov. During his tenure (1843-1875), Bishop Gaganec successfully continued the work of his predecessor, Bishop Tarkovič. He took upon himself a task of firmly establishing the eparchy and securing its future development and prosperity in the mid-19th century. He ensured its organizational stability, financial provision, and pastoral unity. Bishop Gaganec governed his eparchy in very uncertain and complicated times (revolution of 1848-1849, poor harvests, famines, emigration, etc.) that significantly affected his episcopacy. He made every effort to alleviate the social impacts that this period brought upon both the clergy and regular folks. Bishop Gaganec got involved in ecclesiastical and religious reforms, for instance, he introduced a strict liturgical order in the eparchy. He also channelled his effort into improving the religious life of the clergy and congregation. He strongly promoted cultural and publishing activities, which he considered vital for a spiritual life of his flock. Bishop Gaganec participated in almost all cultural activities of Greek Catholics and largely contributed to the establishment of many cultural institutions in the Prešov and Mukachevo eparchies. He also played an important role in the national and political life of Greek Catholic Rusins during and after the revolutionary years of 1848-1849. In appreciation of his many religious, cultural, and national activities, Bishop Gaganec was acknowledged by the Austrian emperor and the Roman Pontiff. He justly deserves the title "the Father of the Prešov Eparchy".

* This research is published with the financial support from IGA PEF ČZU Prague, Nr. 2020 A0013. 
Keywords: Slovak church history, Greek Catholic Church, Eparchy of Prešov, Jozef Gaganec, Rusins in Slovakia.

\title{
Епископ Йозеф Гаганец (1793-1875) - ведущая личность религиозной, национальной и культурной жизни греко-католиков и русинов середины XIX в. в Словакии*
}

\author{
Я.Ш. Цоранич \\ Пряшевский университет в Пряшеве \\ Словакия, 080 01, г. Пряшев, ул. Епископа Гойдича, 2 \\ E-mail: jaroslav.coranic@unipo.sk
}

\section{Авторское резюме}

Йозеф Гаганец был вторым епископом Пряшевской греко-католической епархии (с 1843 по 1875 г.). Он считается одним из виднейших её представителей за всю историю. Епископ Гаганец продолжил дело своего предшественника - епископа Григория Тарковича (секретарём которого был некоторое время) и завершил его начинания. Он окончил процесс создания новой епархии, стабилизировал её и успешно начал дальнейшее развитие епархиальных структур в середине XIX в. Он заботился об организационной стабильности, социальном обеспечении и пастырском единстве. Йозеф Гаганец руководил Пряшевской епархией в сложный период (революция 1848 г., неурожай, голод, эмиграция и т.д.), что существенно повлияло на его епископат. Он тратил много энергии на смягчение социальных последствий того времени не только для духовенства, но и для обычных верующих. Епископ участвовал в церковных и религиозных реформах, ввёл точный порядок богослужений в Пряшевской епархии. Он также приложил большие усилия для совершенствования религиозной жизни опять же не только среди духовенства, но и верующих. Гаганец существенно поддерживал культурную и издательскую деятельность, которую считал очень важной для духовной жизни верующих. Он принимал участие почти во всех культурных мероприятиях греко-католиков, а также в национальной и политической жизни русинов греко-католиков, особенно в революционные 1848-1849 гг. и после них.

* Статья выполнена при поддержке гранта IGA PEF ČZU в Праге, № 2020 A0013. 
Гаганец сыграл значительную роль в создании многих культурных учреждений в Пряшевской и Мукачевской епархиях. Епископа несколько раз награждали австрийский монарх и папа римский за его большие заслуги - религиозную, культурную и национальную деятельность. За активную деятельность его часто называют «отцом Пряшевской епархии».

Ключевые слова: греко-католическая церковь в Словакии, Йозеф Гаганец, Пряшевская епархия, русины в Словакии.

The second bishop of Prešov, Jozef Gaganec [24], is considered one of the most prominent figures of the Greek Catholic Eparchy of Prešov. This Greek Catholic eparchy was erected in 1918 and elevated to archeparchy in 2008. Today it covers the area in the northeast of Slovakia that once bore the name of Prjaševčina [2: 286-287].

Jozef Gaganec was born on 10 April 1793 in Vyšný Tvarožec, near Bardejov as a second child in a family of ten children. His father was a cantor in the local parish church [48:152]. Gaganec received his primary education in Bardejov (1801-1804). From 1804 to 1809, he studied in gymnasium (comprehensive grammar school) in Sátoraljaújheli and completed his secondary education in Levoča in 1810. Having demonstrated his capacity for learning, Gaganec went on to study philosophy to Vel'ký Varadín (1810-1812). In 1812, he was sent for theological studies to Trnava seminary, which he completed with high honours in 1816 [26: 150].

Before his ordination, Gaganec married Anna Kovalická, daughter of Greek Catholic priest in Kány (the Cserehát deanery) Andrej Kovalický. Jozef Gaganec was ordained in Vel'ký Varadín (present-day Oradea in Romania), since the episcopal see of Mukachevo was still vacant and the Eparchy of Prešov was still being formed at that time. He was ordained a deacon on 5 March 1817 and received his holy orders from Bishop Samuel Vulkán of Vel'ký Varadín on 8 March 1817 [45: 27].

The parish of Ruské Pekl'any was the first where the newly ordained priest offered his services. He stayed there until 1820. From 1820 to 1828 Gaganec was the pastor in Viszló in the Boršod deanery. In 1823, Gaganec was appointed an auxiliary dean and in 1827 a dean of the Boršod deanery. From 1828 to 1835, he was the pastor in Héjö-Keresztur [6:1056]. Becoming a widower in 1835, he had to look after his daughter Anna alone.

In 1835, Bishop of Prešov, Gregor Tarkovič appointed Gaganec a member (assessor) of the Consistory, starting his long service in the episcopal curia. After the death of Provost Ján Méhay, the Chapter of Prešov was left with only two canons, Andrej Chira and Bazil Hodobay. 
The appointment of new canons was therefore of vital importance, so, based on the nomination of Emperor Ferdinand I from 3 December 1835, Bishop Tarkovič appointed Michal Jakovič, Bazil Popovič and Jozef Gaganec [7: 16463; 8: 1594; 48: 19]. In 1837, after Canon Popovič was enthroned as the bishop of Mukachevo, Jozef Gaganec was appointed Bishop Tarkovič's Secretary [51:115]. On 7 February 1839, Gaganec was appointed Canon - Cantor of the Prešov Chapter [8: 1594].

Jozef Gaganec was a great help to aging over 80-year-old bishop in all matters pertaining to eparchial administration. It was only natural that following the death of Bishop Tarkovič on 16 January 1841 [27: 94-114], Gaganec became the eparchy's Vicar Capitular assuming responsibilities for administration of the eparchy during sede vacante [9: 48]. Being well acquainted with the situation in the eparchy, Gaganec seemed to be the most suitable candidate for the vacant episcopal see in Prešov. The imperial court in Vienna was of the same opinion. On 13 July 1842, Emperor Ferdinand I nominated Gaganec as the bishop of Prešov and requested the Holy See to confirm this nomination. The Papal office did so on 30 January $1843^{1}$.

Following his nomination, Gaganec travelled to Vienna to deal with all matters concerning the appointment and his future residence [10: 1147]. The second bishop of the Prešov Eparchy was consecrated in the emperor's private chapel in Vienna on 25 June 1843 in the presence of Queen Caroline (Caroline Augusta of Bavaria (1792-1873); widow of Emperor Francis I). The main consecrator was Gaganec's friend and bishop of Mukachevo, Bazil Popovič. He was assisted by titular bishop of Caesarea Cappadocia, Aristaces Azarian and titular bishop of Diocletianopolis (in Palestine), Johann Michael Leonhard. The information about Bishop Gaganec's consecration was delivered to the Greek Catholic faithful in a form of a circular letter on 28 July 1843 [11: 692].

\section{Social and economic provision of the eparchy}

Soon after his consecration, Jozef Gaganec issued his first pastoral letter (28 August 1843) in which he instructed his clergy to work for the spiritual welfare of their people [11:842]. The first half of the $19^{\text {th }}$ century was extremely hard on the peasant population. Living and educational standards were rather low. Poor harvest in 1816-1819 and then again in 1830 made the situation of general population even worse and resulted in terrible famine followed by outbreaks of different epidemics. The 1831-1832 and 1836-1837 cholera outbreak had catastrophic consequences. The regions that were affected the most were the mountain regions of northeast Slovakia dominantly inhabited by Greek Catholics. Bishop Gaganec encouraged his clergy to take care of their impoverished people. He also ordered that from every parish treasury 
one percent of the yearly income should be deposited to the eparchial fund to assist poor parishes. Apart from the financial aid, Bishop Gaganec tried to ease his flock's social and economic situation by offering them practical farming and agricultural advice. He also ordered the priests in his eparchy to teach their parishioners principles of progressive farming and gardening, such as breeding animals, land cultivation, using new agriculture tools, etc. [41:19].

Majority of the Greek Catholic priests were married men with many children. What made their financial situation even worse was the fact that their poor parishioners were unable to pay even the most basic stole fees. In one of his pastoral letters Bishop Gaganec advised his priests to engage in fruit growing and beekeeping so as to be less dependent on their parishioners than before [16:1238].

Besides creating the Eparchial Fund, Bishop Gaganec did his best to resolve the financial provision of his clergy. He knew that securing the clergy financially would give them more time for pastoral work. Bishop Gaganec would repeatedly turn to the authorities with the request to arrange financial provision for his clergy. His relentless efforts bore fruit. On 18 December 1845, Emperor Ferdinand I issued a resolution in which he approved the financial subsidy for the clergy [45: 29]. On 24 February 1846, the Hungarian Supreme Royal Council prepared a concrete project, according to which the congrua, the steady monthly stipend for the clergy of the Prešov Eparchy, was increased. Taking as a base was the description of parish subsidies from 1806 to which 300 florins for every priest was added from the Religious Fund. By this decision, the congrua for the entire clergy of the Prešov Eparchy quadrupled from the amount of 7611 florins and 49.5 kreutzers to $28170 \mathrm{fl}$. and $27.5 \mathrm{kr}$. Each of 167 priests of the eparchy would receive the congrua retroactively effective of 1 November 1845 [48: 162].

After systematization of the congrua, Bishop Gaganec had to resolve another issue concerning the amount of stole fees. The amount differed from parish to parish. On 23 April 1852, the Ministry of Cult issued a regulation setting the stole fee in an amount fixed in 1802. The regulation entered into force on 1 July 1852 [40: 67].

Towards the end of his episcopacy, in 1870, Bishop Gaganec succeeded in obtaining a slight increase of the subsidy for his eparchy. The key for its distribution from 1820 changed, so now $6 / 13$ of the total amount was allocated to the bishop, $6 / 13$ to the Chapter and 1/13 to the cathedral [35: 30].

After resolving the existential question of the clergy, Bishop Gaganec had to tackle another pressing issue - the poor condition of parishes, churches and the ecclesiastical property in general. The opportunity 
for improvement of the economic situation of the parishes arose in the second half of the 1850s and the first half of the 1860s when the land consolidation took place in the eparchy. Bishop Gaganec urged his priests not to miss the opportunity to acquire good land for the parish church, rectory, and parochial school and obtain firewood for the rectory, school and Cantor [17: 1964; 18: 1433].

In his circular letters and during his visitations, Bishop Gaganec repeatedly stressed that taking care of the ecclesiastical property was extremely important. He also asked the individual deans to be strict in their supervision. He would often point out that "bad management and inaccurate bookkeeping kills in people the zeal to sacrifice themselves for the greater good of all and cultivate the ecclesiastical property" [40: 67].

\section{Pastoral activities of Bishop Jozef Gaganec}

The activities of Jozef Gaganec are well documented in his numerous pastoral and circular letters that he regularly sent to the clergy and faithful of his eparchy. In these writings Bishop Gaganec discussed norms for moral conduct, canonical norms (and their internal application among the Greek Catholics as well as their application in relation to the Roman (atholics), liturgical norms, economic, financial and educational matters and offered religious and spiritual encouragement.

His number one priority was to reform the life of his clergy and address negligence of some pastors in the observance of the Byzantine rite. It was common in the eparchy that the priests conducted ceremonies and celebrated liturgies wearing lay clothing or administered baptisms in their rectories. In his pastoral letter, issued on 30 May 1857, he prohibited the clergy from performing religious ceremonies without wearing cassocks. He insisted that his priests wore cassocks on all public occasions and in churches [3: 1857].

In 1857, Bishop Gaganec issued a new liturgical order that would be binding for the entire eparchy. The services were to be performed at the exact time and in a specific order (orthros, holy liturgy, and vespers). Liturgies were to be celebrated after 5 AM in summer and after 6 AM in winter. Priests were encouraged to celebrate liturgies on weekdays too if there was a demand for it. Bishop Gaganec urged priests not to reduce homilies to reading the Gospel and deliver them every Sunday and on every feast day, not just on the major feasts. They should give their best to prepare their homilies. The bishop prescribed his priests to use the Lenten season for fruitful pastoral work. He ordered his priests to take care of the church building, its general maintenance and cleanliness [3: 1857]. In the ordinance issued in 1867, Bishop Gaganec forbade skipping or shortening of the holy liturgy. He reminded his priests of the Pope Pius IX and his work On maintaining ritual purity [52:197]. 
In 1855, the Holy See and the Austro-Hungarian Empire signed a Concordat. Based on this Concordat, Bishop Gaganec issued a decree stipulating that all candidates to a parish or benefice were required to have at least three years of pastoral service and had passed obligatory pro-synodal exams in moral theology and canon law [52: 190]. From those candidates who were planning to marry, the bishop required information about their future wives. It was customary in the eparchy that candidates for priesthood married daughters of already ordained priests. In the context of this old tradition, Bishop Gaganec introduced a decree [4] stipulating that a cleric who did not marry a daughter of the Greek Catholic priest was obliged to donate 800 florins to the Eparchial Fund for Widows and Orphans [5: 1858; 36: 119; 25:119].

In 1845-1847, most of the Slovak regions of Hungary were hit by a severe drought followed by terrible famine and contagious epidemics. On 7 October 1851, Bishop Gaganec appealed to Emperor Franz Joseph I with a request to support the poverty-stricken people of his eparchy. In his letter to the emperor, Bishop Gaganec depicted the pitiful conditions of the Greek Catholics dwelling in the Carpathian mountain regions of Gemer, Spiš, Šariš and Zemplín. He mentioned that they farmed on plots of land with low-fertility soils having only simple tools and equipment at their disposal. The economic and social impact of famine that struck in 1846/47 was amplified by the outbreak of cholera and tuberculosis. The death toll in the Prešov Eparchy reached over 18000 people. Fearing yet another year of bad harvest, famine and epidemics, around 30 000 people (largely Greek Catholics) moved out of eastern Slovakia in 1846/1847. In the years that followed, up until 1851 (when Gaganec wrote his letter to the emperor), another 25000 believers moved to the southern regions of Hungary (south of Zemplín, Sabolč, Banat, and Transylvania) [13: 1304]. In his letter to the emperor, Bishop Gaganec informed about the dire situation of his eparchy whose population decreased rapidly. ${ }^{2}$ Emigration was a persistent phenomenon even after 1851. The regions that were most affected were the Prešov, Vranov and Bardejov deaneries. It is evident from the reports of respective deans compiled in 1852 [14: 983,1035,1042]. To prevent mass exodus of the faithful from the Prešov Eparchy, Bishop Gaganec issued a circular letter urging his clergy to discourage their people from emigrating [14:1210].

Cultural, educational and national issues in the Prešov Eparchy

The improvement of religious life in the Prešov Eparchy is often associated with the arrival of Alexander Duchnovič. In 1843, Bishop Gaganec appointed him a Canon of the Chapter. The bishop found in him a worthy assistant in religious, cultural and educational spheres. To address the lack of textbooks in public schools, Duchnovič would write and, with valuable 
assistance from the bishop, publish textbooks and religious books, for instance: "Книжница читальная для начинающищся”, “Маленкая Библия с картинками," “Краткая земепис," “Катехизия літургический”, “Народная педагогия" and "Хліб души" [1: 115-150].

Chlib duši (The Bread for the Soul) was the first prayer book and a primer intended not only for the people of the Prešov Eparchy, but for the people of the whole Hungary. Having heard about this book from their pastors, the Greek Catholic faithful, majority of whom were basically illiterate, started learning Cyrillic of their own accord so that they could use it to guide their prayers. For Bishop Gaganec, spreading literacy among the villagers was a perfect opportunity for catechization. Not only did the prayer book help to improve the level of education among the faithful, it also contributed to enhancing national consciousness of Greek Catholic Rusins. Bishop Gaganec defended using of Cyrillic because he firmly believed that the introduction of the Latin alphabet would mean the loss of Rusin national and religious identity, gradual Magyarization, and alienation [53:68].

Bishop Gaganec contributed to foundation of various cultural and religious societies. In 1850, under the bishop's patronage, Alexander Duchnovič founded the first literary society of Rusins of the Prešov Eparchy Literarnoje zavedenie Priaševskoje (The Literary Institute of Prešov). The Institute was active only for three years since the government did not approve its statutes. Bishop Gaganec was also one of the co-founders of Matica slovenská in 1863 [33: 178, 194].

Upon his return from Turčiansky Svätý Martin, inspired by the establishment of Matica slovenská, Bishop Gaganec,Alexander Duchnovič and Greek Catholic priest Alexander Pavlovič founded the cultural society Spolok sv. Jána Krstitel'a v Prešove [The Society of St. John the Baptist]. The society published Rusyn literature and its purpose was also to educate young Rusyn intelligentsia ("educated people of secular professions"). In Budapest, Adolf Dobrjansky and Anton Rubij, Secretary of the emperor's commissioner, compiled the statutes. Bishop Gaganec convened a founding assembly to be held in Prešov on 30 October 1862 to which every parish sent up to two delegates. The first assembly was presided by the bishop himself. In his opening speech, he called upon those present to work hard in hope of boosting membership. He proposed establishing an extended committee to run the society. Adolf Dobrjansky was appointed its first chairman [43: 72]. For the gifted youth from the poor Greek Catholic families, Bishop Gaganec established a boarding school called Alumneum [20: 135]. At the assembly of The Society of St. John the Baptist, convened on 11 November 1862, the members discussed 
the concrete issues concerning the foundation of this institution [47: 18]. Following the meeting, the bishop sent to his clergy a circular letter asking them to explain to the faithful the importance of Alumneum and organize a fundraiser to support it. The fundraising was successful; several prominent church dignitaries and state officials contributed to the fund. Emperor Franz Joseph I, for instance, contributed ten thousand crowns. The money raised was used to support five secondary school students in the school year of 1863/64. In 1864, the bishop obtained a building that was adapted for the use of the boarding school and was then opened to students in the school year of 1864/65. At that time, 20 students lived on the premises. Their number rose to 41 in 1875 [47: 21]. In the 90 years of its existence, Alumneum welcomed many students mainly from the poorer population of north-eastern Slovakia. They were given an opportunity to receive education and thus contribute more effectively to the development their region [37: 314].

Bishop Gaganec's effort to ensure elementary education for children in parochial schools in individual parishes was successful too. In 1874, there were 247 schools in the Prešov Eparchy. The language of instruction was a some form of Russian or Rusin language that was close to a local vernacular of the Rusin population [39: 148].

Less successful, however, was the bishop's initiative to establish a Greek Catholic teaching institute. Until then, there was only one teaching institute in Uzhhorod that served both the Mukachevo and Prešov eparchies. Clearly, one institute did not meet the demands for the qualified teachers. Therefore, Bishop Gaganec turned to the Ministry of Education with a request to establish the teaching institute in Prešov. The outbreak of the revolution in 1848 thwarted his plans. Later, the Hungarian Ministry of Education requested the bishop to present his project of the institute. Bishop Gaganec submitted a project elaborated by his secretary, Viktor Dobrjansky [36: 26]. The biggest problem the bishop had to resolve was the financing of the parochial primary and secondary schools. As the state authorities did not provide any funds to cover the establishment of the institute, teacher's salaries, or their accommodation, the whole plan was abandoned for several years to come.

\section{Interritual problems arising from the coexistence of Roman Catholics and Greek Catholics}

We have already mentioned that many Greek Catholic faithful lived in a diaspora among the Roman Catholics. Although the interritual issues were addressed in as early as 1828 , they had not been fully resolved. The ritual adherence of children from the interfaith marriages proved rather difficult. Bishop Gaganec preferred a non-confrontational approach 
to solving these very sensitive issues. He urged his clergy to adopt the same approach in order not to threaten the peaceful co-existence of the two rites.

In many interritual villages, there were no Greek Catholic priests or schools. The children from the interfaith marriages were educated in Roman Catholic schools in the Roman Catholic faith. In addressing these issues, two conflicting opinions prevailed. The Roman Catholic hierarchs argued that in order to establish the ritual adherence of a person it was important to determine the rite in which that person was raised. For the Greek Catholics, on the other hand, the decisive factor was the ritual adherence of the father. The children of the Greek Catholic father were Greek Catholics, whereas the children of the Roman Catholic father were Roman Catholics. In 1856 and 1858, Bishop Gaganec repeatedly turned to the Roman Catholic Bishop of Košice in order to find the best solution that would be acceptable to both parties [5:1858].

In his circular letter issued on 3 April 1859, Bishop Gaganec ordered his priests to visit and care for the faithful who did not have the Greek Catholic church and school in their village. The priests had to make sure that the births and baptisms were correctly entered into the parish registers so as to avoid the situation when the Greek Catholic child baptised in the Roman Catholic church was considered a Roman Catholic [52:190-191]. In his circular letter issued on 22 October 1862, Bishop Gaganec ordered that the children who were born into interfaith families and were considered Catholics of the Byzantine rite according to the Eastern Canon Law were registered in a separate book. Reaching the age of recognition, the children were to be catechised in the Eastern Rite by both the priest and their parents. Bishop Gaganec advised his clergy to turn to the Episcopal See if Roman Catholic priests raised any objections. They were asked to present such cases fully supported with facts and evidence. He also ordered his priests to visit the mixed and Roman Catholic parochial schools at least before Christmas and Easter and hear confessions from the pupils of Greek Catholic faith [52:191-192].

Although Bishop Gaganec tried to eliminate some of the pressure of Latinization in the liturgical life, there was one thing that he willingly adopted from the Roman Catholic Church. Wearing beards by the Greek Catholic clergy was an old tradition. It was a natural thing for the clergymen. Many times the faithful did not "consider" one a priest if he did not wear a beard. During the episcopacy of Bishop Bačinský, the young priests who were not able to grow beards were mocked and called "bezbradnici" (beardless). Even the clergy themselves often had a problem to accept such a priest into their community. For example, in 1774, the clergy of the Makovica deanery condemned the Komloš 
priest who had not worn beard for 15 years. The custom of growing a beard began to fade away, since more and more candidates for priesthood were educated in the Latin rite seminaries [30:95]. The first Greek Catholic bishop who did not wear a beard was Bishop of Mukachevo, Bazil Popovič. His friend, Bishop Gaganec, followed his example. They were both an inspiration for the young clergymen [25:121].A part of the clergy, however, decided to maintain the old tradition. Therefore, in his circular letter issued on 16 September 1862, Bishop Gaganec forbade the priests of his eparchy to wear a beard. He justified his decision by claiming that the Greek Catholic priests who wore a beard were often confused with the Orthodox priests. He explained that by returning to the tradition of the forefathers these priests had also moved closer to the norms of Orthodoxy. For this reason, they had to obey the bishop's order or face punishment since these "Orthodox" manifestations had also raised some suspicion in terms of politics. To priests who argued that they had only held to the discipline of the Eastern Churches, Bishop Gaganec explained that by accepting the Union the clergy had willingly given up some attributes of the Eastern discipline. He urged them to adhere to other norms of the Eastern rite instead of promoting the custom of wearing "rugged" beards. He turned to archdeans and deans and expected of them to endorse this view. He also asked them to "oversee the observance of this prohibition and report everyone who ignored it to the Bishop's Office" [19: 1582].

\section{The revolution of 1848 and its impact on the life in the Greek Catholic Eparchy of Prešov}

Among other factors, poor harvest and prolonged economic crisis sparked a widespread revolutionary wave in Europe in 1848. Bishop Gaganec responded to the precarious social and political situation and convened an eparchial synod to Prešov. The synod was held on 15 June 1848 in the presence of the Canons, the Consistory and 23 priests representing all five archdeaneries [48: 164-165]. Prior to the National Synod in Budapest, all Catholic bishops of Hungary were sent "a questionnaire" consisting of 26 questions concerning the regulations of fasts, erection of new ecclesiastical institutions and organizations, promotion of religious spirit as well as the excess of clergy's engagement in the revolution (which of course meant some indication of pro-or anti-Hungarian sentiment in their dioceses) [38: 103].

At the outset of the revolution, the majority of the Greek Catholic clergy adopted a diplomatic pro-Hungarian stance so they could avoid possible accusations of being disloyal and unpatriotic. Greek Catholic peasants widely welcomed the March Laws and joined the revolutionary Hungarian guards. Despite their pro-Hungarian stance, the Greek 
Catholic clergy was accused of falling prey to Moscow (Russian) agenda ${ }^{3}$. The clergy of the eparchy's Makovica deanery were accused of aversion towards the Catholic Church and of sympathy with Russian Orthodoxy [38:105]. The Hungarians used the term Rus (Orosz) [Russian] to denote both Rusins (Hungarian Russian) and Russians. Therefore, they assumed that all Rusins shared a pro-Russian sentiment [33: 122]. Another reason for the accusations was the fact that many priests ran as members of parliament in the 1848 elections creating a strong competition for secular nobility who feared losing their representation in the parliament. On 27 June 1848, Bishop's secretary Viktor Dobrjansky published an article in Budapesti Hiradó [32:368; 34:24] in which he refuted these allegations, declared that the entire Greek Catholic clergy maintained the pro-Hungarian stance, and vehemently objected the idea of the clergy coming under the influence of Panslavism and Moscow agitation. (It is interesting that Viktor Dobrjansky radically changed his position just a few months later. He rejected the pro-Hungarian orientation and became a leading proponent of a group that openly advocated Rusin national identity) [33: 122-123]. Historian L'udovít Haraksim opines that a majority of the clergy held their pro-Hungarian position until the summer of 1849 , when the Hungarian army was finally defeated. Haraksim sees economic motives behind the fact that the Greek Catholic priests were able to collaborate first with the Hungarians, then, after the end of the revolution, with the Austrian Habsburgs and then again with the Hungarians after the Austrian-Hungarian Compromise (Ausgleich) of 1867. It seems evident that the Greek Catholic clergy collaborated with those who ensured their economic security [33:124].

Until the autumn of 1848, the Greek Catholic clergy favoured the cooperation with the Hungarian government and did not oppose the revolution. The situation changed with the arrival of Adolf Dobrjansky to Prešov. He was a representative of Rusin secular intelligentsia. Under his influence the group of národovci (nation builders and awakeners), mostly members of the Greek Catholic clergy, was formed in Prešov. They engaged in political and cultural activities aimed at revival of the Rusin nation in Hungary. They developed a national-political programme of Rusins in Hungary entitled Pamjatnyk Rusinov Uhorskych and presented it to Emperor Franz Joseph on 19 October 1848. In his speech at the session of the Hungarian Diet, Adolf Dobrjansky demanded autonomy for the Greek Catholic Church in Hungary, the erection of the third eparchy (in Maramaroš), the elevation of the bishop of Mukachevo to a Metropolitan and the creation of a higher administrative body responsible for the governance of the Greek Catholic Church. There were three proposals for the ecclesiastical autonomy of the Greek Catholic Church. The first 
proposal supported independence of the Greek Catholic Church within Hungary headed by the "national party". The supporters of the second proposal inclined towards Hungarians and suggested that the Greek Catholic Church became subordinate to the Roman Catholic Church. The supporters of the third proposal adopted more cautious approach and proposed to take gradual steps to autonomy. The struggle for ecclesiastical autonomy was closely linked with the process of national revival. The clergy was divided in questions concerning state organization. The majority of the clergy leaned towards Austria-Hungary and the Habsburgs whom they considered the guardians of "Russian national identity". This orientation was based in the reforms of Maria Theresa and Joseph II who were in favour of the Greek Catholic Church. The clergy, however, did not stay away from adapting to a given political situation and collaboration with the Hungarian government during the revolutionary years or after the Austrian-Hungarian Compromise in 1867. Only a small portion of the clergy presented their orientation towards Russia stemming from their linguistic closeness and national identity, since they considered themselves a part of the Russian nation [29:144-145].

Bishop Gaganec adopted a neutral stance (contrary to Bishop of Mukachevo, Bazil Popovič, who openly supported the Magyar revolution) and refrained from making any comments about the unfolding events. The bishop's decision proved a wise one. During the revolution of 1848-1849, the town of Prešov was controlled by both rivalling parties. In 1848, the commander of Magyar revolutionaries, General Artur Görgey established his headquarters in the bishop's residence. In June 1849, Prešov was occupied by the Russians [38: 103-104].

Bishop Gaganec was in favour of the revolutionary aims, which promoted modernization, democratization and social changes in Hungary. He fully supported the abolition of servitude and welcomed granting civil and political rights to at least some parts of society. On the other hand, he refused the nationalistic aspects and Magyarization tendencies that the revolution brought. Influenced by their bishop's position, the entire clergy of the Prešov eparchy adopted a more reserved stance towards the Kossuth's revolution. The leading figures of the eparchy respected the sovereign position of Vienna and maintained close relations with the imperial court even after the adoption of the March Constitution [38: 306]. Surely, Bishop Gaganec must have known that it would be easier for the Slavic nations to resist against Magyar supremacy in the multinational Habsburg Empire than in the independent Hungary. To maintain some sort of equilibrium in the Kingdom of Hungary, the Habsburgs partly protected and supported the non-Magyar nationalities living in these territories [39:144]. Bishop Gaganec also maintained a diplomatic stance 
towards the Hungarian government but he strongly disapproved of Magyar nobility's nationalism and their attempts to assimilate the other nations and nationalities [37: 306]. After the end of the revolution, both rivalling parties, the imperial court in Vienna and the ex-revolutionary Magyar circles, disfavoured Bishop Gaganec. Minister of the Interior Alexander Bach even turned to the Hungarian Primate and asked him to deliver an official rebuke to Bishop Gaganec [38: 105]. In Vienna, the governmental circles planned to put the bishop on trial, but this did not happen after all [53: 68]. The Primate also requested from Bishop Gaganec a list of all priests from his eparchy who "revolted" and sided with the Kossuth's revolutionary government [12: 312].

Gradually, the relations between the state officials and Bishop Gaganec settled. In August 1852, Emperor Franz Joseph I visited Prešov. Apart from other town officials, Bishop Gaganec was also there to welcome him. The emperor stopped by the Cathedral of St.John the Baptist and even stayed the night in the bishop's residence [31:279-280].

\section{Bishop Gaganec's "building" activities}

Jozef Gaganec is considered one of the most prominent figures in the history of the Prešov Eparchy. He firmly established the Greek Catholic Eparchy, took care of its organizational stability, social provision, pastoral unity, and secured its further development. His episcopacy will always be associated with the reconstruction of the bishop's residence and remodelling the cathedral for its adaptation to the Eastern Rite.

The bishop's residence is a massive palace-like building located at 1 Hlavná Street in Prešov, next to the Cathedral of Saint John the Baptist. The building with a T-shaped floor plan and a new façade is situated at the former Lower Town Gate and encompasses an older Renaissance longitudinal building. In the rooms, there are Renaissance groin vaults decorated with late Renaissance stucco ornaments. The palace annex, built in 1848, faces the square. Its individual rooms are joined together with Prussian vaults with inter-vaulted strips. The windows on the façade were originally decorated with festoons. The building has an avant-corps divided by pillars and pilasters with a stylized festoon cap, topped with a tympanum. Above the southern wing the dome protrudes through the roof of the building [26:540].

Shortly after his instalment as bishop, Jozef Gaganec turned to Emperor Ferdinand I with a request to build a new part of the bishop's residence. In 1844 - 1845, he turned to the Court Chancery requesting financial assistance. The Chancery approved it and commissioned the court surveyor Wester to prepare the blueprints for the reconstruction. Wester prepared them in 1848. His reconstruction plans proposed building a new residence since a substantial part of the former Minorite monastery 
was demolished in the 1830s. The government allocated 26000 florins from the state treasury. In 1848 , construction works commenced. During this reconstruction, they built a large two-storey palace-like building with a Classicistic façade and a dome on the south side. The builders left an inscription on the front façade of the residence expressing their gratitude to Ferdinand, the Austrian emperor and the Hungarian king. The inscription reads: Ó Fels: V. Ferdinand Magyár Kir: Kegyeségeböl Készult 1848 (Built by His Majesty Ferdinand V, the King of Hungary, 1848). Above the inscription, there is an embossed coat of arms of the Greek Catholic eparchy, which is encircled with a bishop's chain with a cross attached to it. Inside, there was an impressive hall whose walls were covered with portraits of bishops and canons, as well as a bishop's reception office [28: 46-49].

Although most of the construction work was carried out in 1848, the reconstruction was completed after the revolution because the residence was damaged during this unfortunate event. As we mentioned previously, the bishop's residence served as a headquarters for the commander of the Magyar revolutionary army, General Artur Görgey. Some weeks after the departure of the troops, the cost of the property damage was estimated at around 2500 florins. During the town's occupation by the Russian army, the bishop's residence was turned into a military hospital. It was damaged again and had to repaired [44: 3].

Before the reconstruction of his residence, Bishop Gaganec looked to adapt the cathedral for the use of the Byzantine rite. In 1846, he signed a contract with two Viennese artists, sculptor Juraj Roman and painter Albert Tikos who created the iconostasis and the bishop's throne (sedes). The total amount allocated for the iconostasis was 5290 florins (2 800 for Roman and 2490 for Tikos) [44: 3]. In the same year, the main altar (prestol) was decorated according to the Eastern Byzantine tradition. In 1851, the large bell (maior) was added to the three smaller ones. In 1856, the cathedral's tower was raised to its present height, which made it look more magnificent. At the same time, the cathedral was given a new roof and a clock [49: 16-17].

\section{Bishop Gaganec's recognition}

In 1854, in recognition of his many activities, Jozef Gaganec was decorated with the Order of Franz Joseph I [17: 926; 50: 75]. The emperor appointed the bishop his Privy Councillor 1868 [21: 1664]. In the same year, Pope Pius IX elevated Bishop Gaganec to the assistant to the papal throne Solii Pontificii et Comitem Romanum and Count of Rome [21:100]. In 1872, Bishop Gaganec received from the Holy See a pectoral cross with a crown [45: 31]. It is interesting to note that Bishop Gaganec was also appointed an honorary member of the African Institute in Paris [15:1562]. 
In recognition of his apostolic and pastoral work, Bishop Gaganec was delegated to make the visitations of the monasteries belonging to the Order of Saint Basil the Great. In 1858, by order from the Esztergom Archbishop and Hungarian Prelate, Cardinal Ján Scitovský (János Keresztély Cardinal Scitovszky), Bishop Gaganec made visitations of all Basilian monasteries in the Carpatho-Rusyn province (accompanied by Canon of the Prešov Chapter, Alexander Duchnovič) in both the Eparchy of Prešov and Mukachevo. Bishop Gaganec convened all of the superiors to a meeting in Dobromil (Galicia) to discuss the revision of the Basilian Order's statutes. The revised statutes were then presented to the Apostolic See for approval [40:62].

Bishop Gaganec governed his eparchy for 33 years. During his episcopacy, he consecrated two bishops of the Mukachevo Eparchy (Štefan Pankovič and Ján Pásztélyi) and two bishops of Košice. He ordained 237 priests - 190 for the Prešov Eparchy, 22 for the Mukachevo Eparchy, 12 for the Order of Saint Basil the Great and 13 for the other eparchies (12 for the Chelm Eparchy in Poland and 1 for the Lugoj Eparchy in Romania) [48: 169].

In the challenging times of his episcopacy, Bishop Gaganec achieved great things while watching over the welfare of his flock and the entire Church. The times were unpredictable, full of conflicts and major social changes. It was Bishop Gaganec's prudence, reliability, and great organizational skills that helped him put his plans into action even in the most challenging times. Bishop Gaganec was lucky to be surrounded with the like-minded individuals who helped him achieve the set goals. The welfare of his faithful was the bishop's greatest concern. He required the same devotion from the priests in his eparchy. Bishop Gaganec also influenced the secular intelligentsia and encouraged his faithful to be active. Everything the bishop did, he did for the benefit of his people [42: 21; 46: 41].

In his life, Jozef Gaganec was a very humble, courteous, and affable man. He knew no rest in his work. He would wake up before five in the morning. After performing the morning spiritual duties, the bishop would go to his office where he worked the whole day. Except for the consistorial protocol, he worked on all concepts by himself. Although he suffered from chronic weakness and recovered from many serious illnesses, overall he was a healthy man, because he lived a very frugal life [45:31-32]. On 9 May 1852 the press released information about the bishop's serious health condition. According to the printed information, his life was in danger. The bishop fell ill on 1 May. By 8 May, the illness had progressed quickly and Bisop Gaganec grew very weak. Canons even started to prepare him for a journey to eternity [31: 278-279]. 
Bishop Gaganec passed away after a short illness around four o'clock in the morning on 22 December 1875 at the age of 82 in the presence of several local priests. He was buried by Bishop of Mukachevo Ján Kováč Pásztelyi.According to Bishop Gaganec's last wishes, his mortal remains were laid to rest among his faithful in the Prešov cemetery [22:1777].

Around seventy clergymen accompanied their bishop on his last journey. After the funeral, they met in the pub. The correspondent of the Karpat newspaper wrote "their eyes showed that it was not amusement that had brought them there. They met to share the pain and grieffor they were orphaned and abandoned by their beloved father and pastor who was always ready to give his soul a sacrifice for his spiritual sons" [23: 28].

\section{NOTES}

1.There are certain discrepancies in the sources providing the date of Gaganec's nomination by the emperor and the date of his confirmation by the Holy See. The official Schematism and the vast majority of authors state 13 July 1842 as the date of the bishop's nomination and 30 January 1843 as the date of his confirmation. On the contrary, WELYKYJ, Atanaz [54], who published a series of documents from the Vatican Archives concerning the Eastern Catholic Church in Austrian and Hungarian lands states on page 371 (note 63) that the bishop was nominated on 13 July 1842. But he also states that the bishop was confirmed on 29 January 1842 , which clearly does not add up (on pages $371-374$ of this series, Welykyj presents 9 documents concerning the notification of Gaganec's appointment and his confirmation as bishop of Prešov by Pope Gregory XVI (ASV, Reg. Lat., vol. 2232, fol. 314-316). Yet another problem arises when we read the letter of appointment issued by Pope Gregory XVI and which deposited in the Eparchial archives in Prešov. It is dated 3 February 1842. Having compared and evaluated the sources provided in Welykyj's editions and those found in the Eparchial archives in Prešov, we assume that Welykyj must have made a mistake when interpreting the formula ... Anno Millesimo octingentesimo quadragesimo secundo, tertio kalendas Februarii ... as 29 January 1842. It should however be 3 February 1842. (The discrepancy in dates would be resolved if we had the emperor's nomination at our disposal. But such document was not found in the Eparchial archives in Prešov).

2. Bishop J. Gaganec states that the number of the faithful in his eparchy decreased nearly by half. We cannot quite agree with this statement; this figure seems exaggerated. According to the Schematism (1839), there were 174793 faithful in the eparchy and according to the 1851 Schematism their number decreased to 144 342. Even though 
the number of the faithful rose in 1840 - 1846, compared to 1839 (the average increase in 1841-1846 in the whole territory of Slovakia was 0.48\%; See Dejiny Slovenska, c. d., p. 559), a two-fold decrease as of 1851 (as reported by the bishop) is therefore unlikely.

3. Russia signed a treaty with Austria agreeing that the Russian army would help to defeat Hungarian revolutionary forces. Because of that, every manifestation of "pro-Russian" sentiment came under scrutiny.

\section{REFERENCES}

1. Rudlovchak, O. (1965) Tvorchyy shlyakh Dukhnovycha [Dukhnovych's Creative Path]. Oleksandr Dukhnovych [Alexander Dukhnovych]. Proc. of the Conference Dedicated to the 100th Anniversary of His Death (1865-1965). Prešov. pp. 115-150.

2.Sulyak, S. (2019) On the Carpathian Rus'terminology. Rusin. 55. pp. 272-316 (in Russian). DOI: 10.17223/18572685/55/16

3. Gaganec, J. (1857) Circular letter of Bishop J. Gaganec, dated 30 May 1857. The Archive of the Center for East-West spirituality M.Lacko in Košice (ACS VZ).

4. Gaganec, J. (1873) Circular letter of Bishop J. Gaganec, dated 9 April. The Archive of the Center for East-West spirituality M.Lacko in Košice (ACS VZ).1873.

5. Gaganec, J. (1858) Letter from Jozef Gaganec to Bishop of Košice Ignac Fabry, dated 13 June 1858. The Archive of the Center for East-West spirituality M.Lacko in Košice (ACS VZ).

6. The Archive of the Greek Catholic Archeparchy in Prešov (AGAP). Collection: Bežná agenda. Inv. no. 343. Sign. 1056. Year 1827.

7.The Archive of the Greek Catholic Archeparchy in Prešov (AGAP). Collection Listiny. Inv. no. 9. Sign. 16463 - 9. Year 1835.

8. The Archive of the Greek Catholic Archeparchy in Prešov (AGAP). Listiny. Inv. no. 11. Sign. 1594/114 - 7. Year 1839.

9. The Archive of the Greek Catholic Archeparchy in Prešov (AGAP). Bežná agenda. Inv. Nr. 357. Sign. 48. Year 1841.

10. The Archive of the Greek Catholic Archeparchy in Prešov (AGAP). Bežná agenda. Inv. Nr. 358. Sign. 1147. Year 1842.

11. The Archive of the Greek Catholic Archeparchy in Prešov (AGAP). Bežná agenda. Inv. Nr. 359. Sign. 692, 842. Year 1843.

12. The Archive of the Greek Catholic Archeparchy in Prešov (AGAP). Bežná agenda. Inv. Nr. 366. Sign. 312. Year 1850.

13. The Archive of the Greek Catholic Archeparchy in Prešov (AGAP). Bežná agenda. Inv. Nr. 367. Sign. 1304. Year 1851.

14. The Archive of the Greek Catholic Archeparchy in Prešov (AGAP). Bežná agenda. Inv. Nr. 368. Sign. 983, 1035, 1042, 1210. Year 1852.

15. The Archive of the Greek Catholic Archeparchy in Prešov (AGAP). Bežná agenda. Inv. Nr. 369. Sign. 1562. Year 1853. 
16. The Archive of the Greek Catholic Archeparchy in Prešov (AGAP). Bežná agenda. Inv. Nr. 373. Sign. 1238. Year 1857.

17. The Archive of the Greek Catholic Archeparchy in Prešov (AGAP). Bežná agenda. Inv. Nr. 375. Sign. 926, 1964. Year 1859.

18. The Archive of the Greek Catholic Archeparchy in Prešov (AGAP). Bežná agenda. Inv. Nr. 376. Sign. 1433. Year 1860.

19. The Archive of the Greek Catholic Archeparchy in Prešov (AGAP). Bežná agenda. Inv. Nr. 378. Sign. 1582. Year 1862.

20. The Archive of the Greek Catholic Archeparchy in Prešov (AGAP). Bežná agenda. Inv. Nr. 379. Sign. 135. Year 1863.

21. The Archive of the Greek Catholic Archeparchy in Prešov (AGAP). Bežná agenda. Inv. Nr. 385. Sign. 100, 1664. Year 1869.

22. The Archive of the Greek Catholic Archeparchy in Prešov (AGAP). Bežná agenda. Inv. Nr. 391. Sign. 1777. Year 1875.

23. Beskid, M. (2012) Prešovská eparchia. Prešov: Petra.

24. Catholic-hierarchy.org. (n.d.) Jozef Gaganecz. Bishop of Prešov. [Online] Available from: http://www.catholic-hierarchy.org/bishop/bgaganec.html (Accessed: 8th February 2021).

25. Anon. (1970) Blahovistnik Calendar. 1971. Prešov: [s.n.]. pp. 119-121.

26. Matovcik, A. et al. (1987) Slovak Biographical Dictionary. Vol. 2. Martin: Matica slovenská. p.

27.Collective work. (n.d.) List of Historical Monuments in Slovakia. Vol. 2. Bratislava: Obzor.

28. Coranič, J. (2018) Two Hundred Years since the Canonical Erection of the Prešov Greek Catholic Eparchy (September 22,1818). Historia Ecclesiastica. IX/1.pp. 94-114.

29. Coranič, J. (2007) Architectural Development and Artistic Decoration of the Cathedral of St. John the Baptist and the Episcopal Residence. In: History of the Cathedral of St. John the Baptist and the Episcopal Residence in Prešov. Prešov: Petra. pp. 46-49.

30. Danilák, M. (2008) The Influence of Greek Catholic Church on the Formation of National Consciousness of Rusyns (Ukrainians). In: Churches and Nations of the Central Europe (1800-1950). Prešov: Universum. pp. 134-148.

31. Duchnovič, A. (1877) Chronological History of the Famous Prešov Eparchy from its Origin to Bishop Gregor Tarkovič. St. Petersburg.

32. Duchnovič, O. (1989) Writings III. Bratislava: Slovenské pedagogické nakladatel'stvo. pp. 278-279.

33. Haraksim, L'. (1960) The Movement of Ukrainians in Transcarpathia and Eastern Slovakia and the Ideas of Slavic Reciprocity. Historický časopis. 8(2-3). pp. 360-375.

34. Haraksim, L'. (1961) On the Social and Cultural History of Ukrainians in Slovakia before 1867. Bratislava: SAV.

35. Haraksim, L'. (2000) The Golden Age of Bishop A. Bačinský and the Revival Period of A. Duchnovič - Two Epochs of the Rusyn History. In: Slovak - Rusyn - Ukrainian Relations from the Revival to the Present. Bratislava: [s.n.]. 
36. Hrivnák, S. (1968) The Greek Catholic Eparchy of Prešov 1323-1821-1950. Prešov: Gréckokatolícke biskupstvo v Prešove.

37. Janočko, M. (2007) Church Elementary Education in the Prešov Eparchy, 1818-1918. In: History of the Church Greek Catholic Education in Slovakia I. Prešov: GTF PU. pp. 20-40.

38. Konečný, S. (2013) Bishops J. Gaganec and P. P. Gojdič: Historical Parallels and Differences. In: The Greek Catholic Church in Slovakia in the light of anniversaries III. Prešov: GTF PU. pp. 311-323.

39. Kubinyi, J. (1970) The History of Prjašiv Eparchy. Romae: [s.n.].

40. Magocsi, P.R. (1994) Rusyns in Slovakia: A Historical Overview. Prešov: Rusínska obroda.

41. Murín, J. (1943) History of the Greek Catholic Eparchy of Prešov during the Episcopacy of its First Two Bishops (1787-1876). Dissertation. Michalovce.

42. Pekar, A. (1968) Historic Background of the Eparchy of Prjashev. Pittsburgh: Byzantine Seminary Press.

43. Petrík, V. (2011) Bishop Jozef Gaganec and His Era. Diploma thesis. Prešov: GTF PU in Prešov.

44. Popovec,J. (2008) Society of John the Baptist in the Religious and National Life of Rusyns. In: Rusyn Culture and Education after 1989. Prešov: University of Prešov in Prešov. pp. 69-81.

45. Anon. (1876) Remembering Blessed Bishop losif. Karpat. 4(4). p. 3.

46. Ruby,J.(1903) Brevis historia dioecesis Eperjesiensis II. In: Catholic Church. Schematismus venerabilis cleri graeci ritus catholicorum dioecesis Eperjesiensis pro anno domini 1903. London: [s.n.]. pp. 3-41.

47. Rudlovčáková, H. (1996) Jozef Gaganec and Four Apprenticeships of Subcarpathian Ukrainians. Dukla. Vol. 41(2). pp. 41-51.

48. Russnák, M. (1907) History of the Alumneum. Eperjes: [s.n.].

49. Sass, B. (1957) Biographia secundi episcopi losephi Gaganecz. In: A Contribution to the History of the Prešov Eparchy. Manuscript. Romae: [s.n.]. pp. 152-171.

50. Catholic Church. (1931) Schematismus Venerabilis Cleri Graeci Ritus Catholicorum Dioeceseos Fragopolitanae (Prešov - Prjašev) pro anno Domini 1931. Ab erecta Sede Episcopali anno 115. Fragopoli: [s.n.]. pp. 16-17.

51. Šturák, P. (1999) History of the Greek Catholic Church in Czechoslovakia, 1945-1989. Prešov: [s.n.].

52. Vasil', C. (2000) Greek Catholics. History - fortunes - personalities. Košice: Byzant.

53. Vasil', C. (2000) Canonical Sources of the Byzantine-Slavic Catholic Church in the Mukachevo and Prešov Eparchies in Comparison with the Code of Canons of the Eastern Churches. Trnava: Dobrá kniha.

54. Vasil', C. (1995) He Sought the Spiritual and Material Welfare of his People. (On the 120th Anniversary of the Death of the Second Bishop of Prešov, Jozef Gaganec). Greek Catholic Calendar. p. 68.

55. Welykyj,A. (1954) Documenta Pontificorum Romanorum historiam Ucrainae illustrantia. Vol. II. Romae: [s.n.]. 
Цоранич Ярослав Штефанович - кандидат философских наук, доцент, заведующий кафедрой исторических наук греко-католического теологического факультета Пряшевского университета, заместитель декана греко-католического теологического факультета по образованию и аккредитации (Словакия).

Coranič Jaroslav - Prešov University in Prešov (Slovakia).

E-mail: jaroslav.coranic@unipo.sk 